\title{
Study of consanguinity of the population of northern Morocco
}

Ossmani $\mathrm{HE}^{1^{*}}$, Ouardani $\mathbf{M}^{2}$, Habibeddine $\mathrm{L}^{1}$, Amzazi $\mathbf{S}^{1}$ and Talbi $\mathbf{J}^{1}$

${ }^{1}$ Faculty of Sciences, University Mohammed V-Agdal Rabat-Morocco

${ }^{2}$ Faculty of Sciences, University Mohammed I- Oujda-Morocco

*Corresponding author: Hicham El Ossmani, Faculty of Sciences, University Mohammed V-Agdal Rabat-Morocco, Tel: 0021260311013111; E-mail: helossmani@yahoo.fr

Received date: December 26, 2017; Accepted date: January 09, 2018; Published date: January 15, 2018

Copyright: (c) 2018 Ossmani HE, et al. This is an open-access article distributed under the terms of the Creative Commons Attribution License, which permits unrestricted use, distribution, and reproduction in any medium, provided the original author and source are credited.

\begin{abstract}
Consanguinity is a matrimonial behavior that is much perpetuated in the Arabo-Muslim world. This behavior contributes to the impoverishment of the genetic heritage of populations by increasing the genetic homogeneity, influencing, thus, the state of the public health. Belonging to the Arabo-Muslim world, the North population of Morocco has been partially studied to characterize this matrimonial behavior from an anthropogenetic point of view.

Sample of 1588 couples belonging to the population of northern Morocco has been studied. The results showed a level of consanguinity very close to the national average $(24.37 \%)$. Marriages between first cousins are most widespread among the other types of consanguineous unions $(63.18 \%)$. Furthermore, specific features seem to characterize the practice of consanguinity in Morocco's northern region, which respond to many socioeconomic, cultural, historical and geographical factors.
\end{abstract}

Keywords: Consanguinity; Anthropogenetic; Morocco; North Population

\section{Introduction}

Marriage remains a sacred relationship heavily influenced by ethnographic, socio-economic and geographic factors [1]. In populations, unions are generally made either between related individuals [2] or randomly [3]. Intermarriage is a form of unions widely practiced in Arab societies in which endogamy plays a major role [4]. Therefore this behavior contributes to the depletion of the gene $[5,6]$ and increasing degrees of homogeneity among populations [7].

Inbreeding is defined as the existence of a relationship between two individuals from a direct lineage (grandfather, father, son, grandson) or collateral line (brother, cousin, uncle, nephew) [8]. The different types of consanguineous marriages are maintained or eliminated under the pressure of the major factors (culture, history and religion) that characterize societies in the world. In Arab society, heads of families (grandparents and fathers), require or encourage marriages within the same family (especially between cousins), with the aim to preserve property and to avoid family conflicts related to inheritance (agnate). Incestuous marriages between brothers and sisters, uncles and nephews, and of course between fathers and daughters are forbidden in these societies by law and religion.

The development of infrastructures, transport, and telecommunications means greatly influence the degree of inbreeding, reducing borders and enlarging the scope of choosing a spouse.

Several studies have been conducted on inbreeding in different countries. Arab countries are known by a remarkably high level compared to Europe and the United States. First, the highest inbreeding levels are recorded in the Golf countries, $64.3 \%$ in Kuwait [9], 50.5\% in Saudi Arabia [10].
Moreover percentages of $22.8 \%$ [11], 42\% [12] and 39.8\% [13] respectively, were observed in the Middle East (Egypt, Lebanon and Syria). Similar figures have been denoted in the studies on the North African countries with $47.2 \%$ in Mauritania [14] and $32.71 \%$ in Tunisia [8]. Studies on Moroccan population on different periods, reported inbreeding percentages between $19 \%$ and $23 \%[15,16]$.

In this study we try to assess the level of inbreeding in a Moroccan population on which the data are still fragmentary. This study is about the population of northern Morocco.

\section{Populations and Methods}

\section{Studied population}

To study inbreeding among the population of northern Morocco, it is not enough to rush to DNA analysis. Human species being the subject of the study, language settings, political and religious, ethnic, cultural, socio-economic and geographic [17], should necessarily be considered to understand the motivations behind this marital practice.

From a geo-ethnic and linguistic point of view, Northern Morocco is considered the territory of Jebala and Rif tribes. Jebala occupy the Northwest Mountains, they speak Jebli somehow similar to the Moroccan Arabic. Meanwhile Rif occupy the center and east of the North of Morocco and speak Tarifit.

From a historical view point, northern Morocco has experienced decades of important historical facts that may influence its genetic patrimony, creating heterogeneous populations. The Almoradives conquest of Andalusia started a 711 [18] are the most striking, indeed from that date, the Muslims conquered the Iberian Peninsula during a period of 700 years, and during the Christian re-conquest between 1406 and 1492[19], most Muslims driven out of Andalusia migrated to northern Morocco. 
From a demographic point of view the following (Table 1) summarizes the distribution of the total number of citizens in the northern provinces of Morocco.

\begin{tabular}{|c|c|c|c|}
\hline $\begin{array}{l}\text { Region, Province or Prefecture (Urban } \\
\text { and rural) }\end{array}$ & $\begin{array}{l}\text { Populati } \\
\text { on }\end{array}$ & $\begin{array}{l}\text { Foreigne } \\
\text { rs }\end{array}$ & $\begin{array}{l}\text { Morocca } \\
\text { ns }\end{array}$ \\
\hline Province: Al Hoceima & 399,654 & 236 & 399,418 \\
\hline Province: Chefchaouen & 457,432 & 143 & 457,289 \\
\hline Province: Fahs-Anjra & 76447 & 44 & 76,403 \\
\hline Province: Larache & 496,687 & 413 & 496,274 \\
\hline Province: Ouezzane & 300,637 & 134 & 300,503 \\
\hline Prefecture: Tanger-Assilah & $\begin{array}{l}1,065,60 \\
1\end{array}$ & 5,299 & $\begin{array}{l}1,060,30 \\
2\end{array}$ \\
\hline Province: Tétouan & 550,374 & 605 & 549,769 \\
\hline Prefecture: M'Diq-Fnideq & 209,897 & 579 & 209,318 \\
\hline Province: Guercif & 216,717 & 75 & 216,642 \\
\hline Province: Taounate & 662,246 & 81 & 662,165 \\
\hline Province: Taza & 528,419 & 138 & 528,281 \\
\hline
\end{tabular}

Table 1: Distribution of the total number of citizens in the northern provinces of Morocco (Sixth General Census of Population and Housing conducted between the 01 and 20th September 2014).

\section{Sampling}

The study took place during the year 2015, and focused on a sample of 1588 informed and consent couples. This is a retrospective study in which two methods were used, the open interview method associated with a data collection on a previously established questionnaire.

These couples belong ancestrally and linguistically to the population of northern Morocco. Indeed volunteers speak Tarifit or Jebli (the only two dialects of the region), and they are native to the region of 3 ancestral generations.

\section{Results and discussions}

Morocco has suffered during the colonial period, including the northern region, which undergoes a dual French and Spanish colonization. Since the region has lived in a state of isolation and marginalization compounded by the lack of infrastructure and the geography of the area.

(Table 2) summarizes the dialect distribution in the population of Northern Morocco.

\begin{tabular}{|c|c|c|}
\hline \multicolumn{3}{|c|}{ Number of couples } \\
\hline Jebli & 1,452 & 9,144 \\
\hline Rifi/Jebli & 136 & 856 \\
\hline Total & 1,588 & 10,000 \\
\hline
\end{tabular}

Table 2: Distribution of the couples by dialect.
Underdevelopment and economic difficulties in the region have favored the migration of the Rifi population to Europe and to major cities of the north like Tangier and Tetouan. The new situation creates a generation that speaks both Jebli and Rifi/Jebli dialects (Table 3), while the dialect Rifi has become very rare in the last generation, compared to the generation of grandparents who still reside in the Rif.

In the population of northern Morocco, the percentage of consanguineous couples is $24.37 \%$, it is around the national average but is still lower compared to the percentage recorded by a study on the population of Tangier-Tetouan (39\%) [20]. 14.86\% of consanguineous unions statements, are contracted between spouses whose relationship is undefined (Table 3). The accumulation of inbreeding within the family lines makes relationship between spouses so complicated and it becomes very difficult to define. Similarly, the relationship between the spouses is so old that they end up forgetting its nature. Moreover, unions between first cousins are the most contracted with a percentage of $8.82 \%$. On the other hand the frequency of other unions is very low (Table 3).

\begin{tabular}{|c|c|c|c|c|}
\hline \multirow{2}{*}{$\begin{array}{l}\text { Relationship } \\
\text { Double first cousins }\end{array}$} & \multicolumn{2}{|c|}{ Coefficient of consanguinity } & \multirow{2}{*}{$\begin{array}{l}\text { (n) } \\
1\end{array}$} & \multirow{2}{*}{$\begin{array}{l}\% \\
0.06\end{array}$} \\
\hline & 8-Jan & 0.125 & & \\
\hline Second cousins & Jan-64 & 0.01562 & 7 & 0.44 \\
\hline Unequal cousins & Jan-32 & 0.03125 & 3 & 0.19 \\
\hline First cousins & 16-Jan & 0.0625 & 140 & 8.82 \\
\hline Undefined relationship & 0.0998 & 0.0998 & 236 & 14.86 \\
\hline No relationship & 0 & 0 & 1201 & 75.63 \\
\hline
\end{tabular}

Table 3: The distribution of inbreeding by relationship among the Moroccan northern population.

This distribution of inbreeding in Morocco's northern population is genetically expressed by a coefficient of inbreeding that reached in our case 0.008038 .

This percentage is also lower than those revealed in the Doukkala region by $26.3 \%$ [21] and among the population of Fritissa in the Middle Atlas by $30.32 \%$ [22]. Nevertheless the inbreeding percentage recorded in northern Morocco is higher compared to the one denoted on the population of Gharb $20.06 \%[23,24]$. Different relationships are as follows (Table 4).

\begin{tabular}{|l|l|l|}
\hline Description & $(\mathbf{n})$ & $\%$ \\
\hline Father's sister's daughter & 13 & 9.28 \\
\hline Daughter of the mother's brother & 14 & 10 \\
\hline Daughter of the mother's sister & 24 & 17.13 \\
\hline Daughter of the father's brother & 89 & 63.56 \\
\hline
\end{tabular}

Table 4: Distribution of first cousins to the types of unions.

The analysis of the choice of inbred spouse emphasizes a preference for cousins; However, there is a preferential affinity even within this category of inbreeding. This preference may locate Morocco's northern population in its anthropological and societal context. 
Indeed in case of a patriarchal society, a clear preference is noticed for unions with the father's brother's daughter (63.56\%).

In this kind of society, the choice of spouse is literally dependent on the will of the Father who loves to guarantee the transmission of the family name to his little sons.

Table 5 shows the distribution of different types of consanguineous marriages by place of birth.

\begin{tabular}{|l|l|l|}
\hline$\%$ & Urban & Rural \\
\hline undefined & 20.9 & 13.25 \\
\hline CG & 8.65 & 8.87 \\
\hline CIG & 0.6 & 0.4 \\
\hline CI & 0 & 0.24 \\
\hline DCG & 0 & 0.08 \\
\hline$\%$ Ca & 30.15 & 22.83 \\
\hline P.P & 69.85 & 77.17 \\
\hline Total & 1253 & 335 \\
\hline
\end{tabular}

Table 5: Distribution of inbreeding types by place of birth; CG: First cousins; CIG: Second cousins; CI: Uniqual cousins; DCG: Double first cousins; Ca: Consanguinity; P.P: No relationship.

Of the 1588 couples studied 1253 couples reside in the rural areas, however, the inbreeding in the urban environment is more high $(30.15 \%)$, this result is the same for the inbreeding coefficient reaches 0.0089052 in urban environment and 0.0076556 in rural areas. Comparing the types of links between the two environments, the category of undefined relationship is higher in the urban areas than rural ones. Indeed traditions are deeply rooted in the rural population, and it has a much stronger collective memory than the urban population.

The increased percentage of inbreeding in urban areas may be due to selection of consanguineous native of rural and enriched by accumulation of properties, allowing it to populate the neighboring urban centers. This situation is rather special compared to published results on other Moroccan populations. Talbi [21] reported no significant difference in inbreeding in studies conducted on the population of Doukalas and overall population of Morocco. However a rather high inbreeding in rural areas has been denoted in a study on the population of Gharb [23].

The environment could certainly affect this behavior [24-27], but we still need to ensure the reliability of barriers and criteria that defines the rural and urban areas.

\section{Conclusion}

According to this study it was shown that the population of northern Morocco has a lower inbreeding compared to other Moroccan populations, with a clear preference for marriages between first cousins that are the most common (36.18\%). This marital behavior is less perpetuated in rural areas for this population.

Several factors have contributed over time to the enrichment of the population structure of the region and the diversification of its population. Indeed the development of means of transport, infrastructure and major economic projects in this part of Morocco gave a strategic dimension to the region and contributed to the attractiveness of its cities.

These factors had a palpable impact on the socio-cultural environment of the people of Northern Morocco, which could create a more or less an open and permissive generation. The role of women is important in these changes by becoming active in society and a good financial partner in her family. Choice of spouse also became a right either to the woman or the man.

\section{References}

1. Mielke JH, Relethford JH, Eriksson AW (1994) Temporal trends in migration in the Aland Islands: Effects of population size and geographic distance. Hum Biol 66: 399-410.

2. Blackwell DL (1998) Marital homogamy in the United States: The influence of individual and paternal education. Soc Sci Res 27: 159-188.

3. Roberts DF (1976) Insulation concepts in: the study of the isolates. INED Paris 75-92.

4. Jacques Vallin GC, Wunsch WJ (2004) Demography: Population and society. INED.

5. André Chaventré (1983) Evolution anthropo-biological a Tuareg population. Kel Kummer and their relatives, numbers 103 to 104. INED.

6. Talbi J, Khadmaoui AE, Sulayman AEM, Chafik AEA (2007) Study of inbreeding in the Moroccan population. Impact on the health profile. Antropo 15: 1-11.

7. Tabah L, Stutter J (1952) Effects of inbreeding and inbreeding: A survey in Morbihan and Loir-et-Cher. Persee 7: 249-266.

8. Mrad LB, Chalbi N (2004) The marital choice in Tunisia is it transmissible? Antropo 7: 31-37.

9. Radovanovic Z, Shah N, Behbehani J (1999) Prevalence and social correlates to consanguinity in Kuwait. Ann Saudi Med 19: 206-210.

10. Al-Gazali LI, Bener A, Abdulrazzaq YM, Micallef R, al-Khayat AI, et al. (1997) Consanguineous marriages in the United Arab Emirates. J Biosoc Sci 29: 491-497.

11. Mohamed MS (1995) An epidemiological study on consanguineous marriage among urban population in Alexandria. J Egypt Public Health Assoc 70: 293-305.

12. Barbour B, Salameh P (2009) Consanguinity in Lebanon: Prevalence, distribution and determinants. J Biosoc Sci 41: 505-517.

13. Othman H, Saadat M (2009) Prevalence of consanguineous marriages in Syria. J Biosoc Sci 41: 685-692.

14. Hammami A, Elgazzeh M, Chalbi N, Mansour BA (2005) Endogamy and consanguinity in Mauritania. Tunis Med $83: 38-42$.

15. Baali A (1994) Anthropological study of a Berber population of semiinsulated High Atlas: Valle d'Azgour, circle Amizmiz, Marrakech. Semlalia thesis, Faculty of Sciences, Marrakech.

16. Lamdouar BN (1994) Consanguinity and public health in Morocco. Bull Acad Natl Med 178:1013-1025.

17. Mouna K (2008) For another approach anthropological case study of the rif of Morocco, Anthropol Soc 32: 101-106.

18. Khaldoun I (1925) History of the berbers and the muslim dynasties of the holland Africa. Geuthner Paul, Paris.

19. Glick MP (1979) Islamic and Christian Spain in the Early Middle Ages: Comparative Perspectives on Social and Cultural Training. Princeton University Press, Princeton.

20. Hardouz H, Hami H, Mokhtari A, Soulaymani A, Sbai (2014) Consanguineous marriages profile in the Tanger-Tetouan region in Morocco. IOSR J Pharm Biol Sci 9: 61-67.

21. Talbi J, Khadmaoui A, Soulaymani A, Chafika A (2008) Characterization of the evolution of inbreeding in the population of Doukkala (Morocco). Antropo 17: 7-13. 
Citation: Ossmani HE, Ouardani M, Habibeddine L, Amzazi S, Talbi J (2018) Study of consanguinity of the population of northern Morocco. J Forensic Res 9: 406. doi:10.4172/2157-7145.1000406

Page 4 of 4

22. Latifi M, Khadmaoui A, Soulaymani A, Mokhtari A (2004) Reproduction system in a human population Solee Middle Atlas of Morocco (population Fritissa). Antropo 7: 73-78.

23. Attazagharti N, Hami H, Soulaymani A, Benali D, Khadmaou A, et al. (2006) Inbreeding and isonymy in the Gharb region in Morocco. Bio Health 6: 2.

24. Hami H, Attazagharti N, Soulaymani A, Mokhtari A (2005) Homogamy in the region of Gharb-Chrarda-Beni Hssen (MOROCCO). A prospective study (June 2003-February 2004). Antropo 9: 51-60.
25. Al-Awadi SA, Moussa MA, Naguib KK, Farag TI, Teebi AS, et al. (1985) Consanguinity among the Kuwaiti population. Clin Genet 27: 483-486.

26. Attazagharti N (2002) Influence of socio-economic and cultural factors on inbreeding in the region of Gharb-Chrada-Beni Hssen. Master Thesis, Fac Sci Kenitra.

27. Moussouni A, (2012) Biological anthropologists study of inbreeding on fitness parameters and morbidity in the population of Sabra in Western comparative study in the Mediterranean basin. Doctoral thesis. Faculty of Humanities and Social Sciences Tlemcen, Algeria. 